\section{(6) OPEN ACCESS}

REVIEW

\title{
Transcranial direct current stimulation (tDCS) and language
}

\author{
Alessia Monti, ${ }^{1}$ Roberta Ferrucci, ${ }^{2,3}$ Manuela Fumagalli, ${ }^{2,3}$ Francesca Mameli, ${ }^{2}$ \\ Filippo Cogiamanian, ${ }^{2,4}$ Gianluca Ardolino, ${ }^{2,4}$ Alberto Priori ${ }^{2,3}$
}

\begin{abstract}
${ }^{1}$ Centro Interdipartimentale Mente/Cervello (CIMeC), Centro di Riabilitazione Neurocognitiva (CeRiN), Università degli Studi di Trento, Rovereto, Italy

${ }^{2}$ Centro Clinico per la Neurostimolazione, le Neurotecnologie ed i Disordini del Movimento, Fondazione IRCCS Ca' Granda Ospedale Maggiore Policlinico, Milano, Italy

${ }^{3}$ Dipartimento di Fisiopatologia Medico-Chirurgica e dei Trapianti, Università degli Studi di Milano, Milano, Italy ${ }^{4}$ U.O. di Neurofisiopatologia, Fondazione IRCCS Ca' Granda Ospedale Maggiore Policlinico, Milano, Italy
\end{abstract}

\section{Correspondence to} Professor Alberto Priori, Centro Clinico per la Neurostimolazione, le Neurotecnologie ed i Disordini del Movimento, Fondazione IRCCS Ca' Granda, Ospedale Maggiore Policlinico, Via Francesco Sforza, 35-20122 Milano, Italy; alberto.priori@unimi.it

Received 21 March 2012 Revised 27 September 2012 Accepted 28 September 2012 Published Online First 8 November 2013

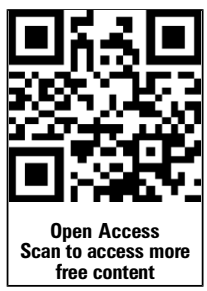

To cite: Monti $A$, Ferrucci $R$, Fumagalli $M$, et al. I Neurol Neurosurg Psychiatry 2013;84: 832-842.

\section{ABSTRACT}

Transcranial direct current stimulation (tDCS), a noninvasive neuromodulation technique inducing prolonged brain excitability changes and promoting cerebral plasticity, is a promising option for neurorehabilitation. Here, we review progress in research on tDCS and language functions and on the potential role of tDCS in the treatment of post-stroke aphasia. Currently available data suggest that tDCS over language-related brain areas can modulate linguistic abilities in healthy individuals and can improve language performance in patients with aphasia. Whether the results obtained in experimental conditions are functionally important for the quality of life of patients and their caregivers remains unclear. Despite the fact that important variables are yet to be determined, tDCS combined with rehabilitation techniques seems a promising therapeutic option for aphasia.

\section{INTRODUCTION}

Although all social animals communicate with each other, only humans have developed language, a system of finite arbitrary symbols combined according to grammar rules and able to transfer infinite meanings. ${ }^{1}$ Aphasia is a language disorder that results from damage to the brain generally localised in the left hemisphere. ${ }^{2}$ Aphasic impairment in the ability to speak, understand, repeat, write and read varies widely from patient to patient and depends on the type of aphasia. Aphasia can also coexist with abnormal motor speech programming called apraxia of speech or verbal apraxia, a disorder characterised by an impaired ability to coordinate the sequential, articulatory movements necessary to produce speech sounds.

As well as studies in patients with brain lesions, neuromodulation techniques have provided clues on the neural circuits underlying normal language, and helped to explain the pathophysiology of aphasia and its recovery. In an early study, conducted in 1965, Penfield reported that electrical stimulation delivered to the posterior speech area of the cerebral cortex (Wernicke's area) caused an arrest of speech, making the subject transiently aphasic. $^{3}$ Although studies using intraoperative stimulation to the exposed brain continued over the following decades, ${ }^{4-6}$ a major insight into the brain mechanisms underlying cognitive functions and speech in the past decade has come from noninvasive brain stimulation: transcranial magnetic stimulation (TMS) and, more recently, transcranial direct current stimulation (tDCS). ${ }^{7}$ TMS and tDCS can both modulate motor, sensory, cognitive and behavioural responses. ${ }^{8-10}$ The possibility of influencing brain activity with TMS ${ }^{11}{ }^{12}$ or tDCS $^{13} 14$ has increased scientific interest in how modulating brain excitability influences the human language network. Early results suggest that these techniques may also have therapeutic potential and may therefore provide a further complementary strategy in treating aphasia. ${ }^{15} 16$

This review aims to discuss data on the use of tDCS for the modulation of language in healthy individuals (table 1) and in patients with aphasia (table 2). We used the PUBMED online database to select papers published from March 2005 to January 2012. Our key search terms were 'tDCS' or 'transcranial direct current stimulation' or 'brain polarisation' combined with 'language' or 'aphasia'. All studies selected for review had to be conducted in humans and were papers written in English (figure 1).

\section{FUNDAMENTALS OF tDCS}

tDCS modulates spontaneous neuronal activity through a weak direct current delivered on the scalp inducing prolonged functional after-effects in the brain. The stimulating electrode is placed over the target area and the reference electrode can be placed on the scalp ('bicephalic or bipolar tDCS') or on a different body part, usually the right shoulder ('monocephalic or monopolar tDCS'). tDCS is considered safe and induces no major adverse effects. $^{17} 18$

Although the mechanisms of action of tDCS still also need to be clarified in healthy individuals, it is generally accepted that different effects on brain excitability may be obtained according to current polarity, intensity and duration of the stimulation. In general, at least in normal individuals, anodal stimulation is supposed to depolarise neurones leading to an increase in excitability, whereas cathodal stimulation has the opposite effect. The mechanisms of tDCS are classified into synaptic (changes by altering the strength of synaptic transmission) and non-synaptic (shifts in resting membrane potential of pre and post-synaptic neurones). ${ }^{1920}$

The mechanisms during stimulation are probably different from those responsible for short and longlasting after-effects. ${ }^{19-28}$ The tDCS effect during stimulation is induced by modulation of the resting membrane potential, while the long-lasting aftereffect can be explained by multiple mechanisms, primarily the induction of long-term potentiation 
Table 1 tDCS studies on language functions in healthy individuals

\begin{tabular}{|c|c|c|c|c|c|c|c|c|c|c|c|c|c|}
\hline $\begin{array}{l}\text { Studies on } \\
\text { healthy subjects }\end{array}$ & Subjects & $\begin{array}{l}\text { Age } \\
\text { mean } \\
\pm \mathrm{SD} \\
\text { years }\end{array}$ & $\begin{array}{l}\text { Education } \\
\text { years }\end{array}$ & Polarity & $\begin{array}{l}\text { Electrode } \\
\text { size }(\mathrm{cm})\end{array}$ & $\begin{array}{l}\text { Stimulated } \\
\text { areas }\end{array}$ & $\begin{array}{l}\text { Reference } \\
\text { electrode }\end{array}$ & Control areas & $\begin{array}{l}\text { Intensity/ } \\
\text { duration }\end{array}$ & Task & $\begin{array}{l}\text { Online/ } \\
\text { offline }\end{array}$ & Effects & Follow-up \\
\hline \multicolumn{14}{|l|}{ Frontal tDCS } \\
\hline lyer et $a l^{39}$ & $\begin{array}{l}103(47 \\
\text { men) }\end{array}$ & $\begin{array}{l}37.5 \\
\pm 12.9\end{array}$ & $\geq 12$ & $\mathrm{~A} / \mathrm{C} / \mathrm{S}$ & $5 \times 5$ & $\begin{array}{l}\text { Left dorsolateral } \\
\text { prefrontal cortex }\end{array}$ & $\begin{array}{l}\text { Contralateral } \\
\text { supraorbital area }\end{array}$ & No & $\begin{array}{l}1 \text { and } \\
2 \mathrm{~mA} / \\
20 \mathrm{~min}\end{array}$ & $\begin{array}{l}\text { Verbal fluency } \\
\text { (phonemic cue) }\end{array}$ & Offline & $\begin{array}{l}\text { Anodal tDCS ( } 2 \mathrm{~mA}) \\
\text { improves verbal fluency }\end{array}$ & No follow-up \\
\hline Fertonani et $a l^{41}$ & $\begin{array}{l}12 \text { (4 men) } \\
12 \text { controls } \\
(6 \text { men) }\end{array}$ & $\begin{array}{l}24.1 \pm 3.7 \\
21.8 \pm 1\end{array}$ & DNR & $A / C / S$ & $5 \times 7$ & $\begin{array}{l}\text { Left dorsolateral } \\
\text { prefrontal cortex }\end{array}$ & Right shoulder & No & $\begin{array}{l}2 \mathrm{~mA} / 8 \text { and } \\
10 \mathrm{~min}\end{array}$ & Picture naming & Offline & $\begin{array}{l}\text { Anodal tDCS reduces } \\
\text { latency of response }\end{array}$ & No follow-up \\
\hline De Vries et $a l^{42}$ & $\begin{array}{l}44(21 \\
\text { men) } 6 \\
\text { excluded } \\
10 \text { controls } \\
\text { ( } 5 \text { men) }\end{array}$ & $22.6 \pm 2.1$ & $>15$ & $A / S$ & $5 \times 7$ & $\begin{array}{l}\text { Left inferior } \\
\text { frontal gyrus }\end{array}$ & $\begin{array}{l}\text { Contralateral } \\
\text { supraorbital area }\end{array}$ & $\begin{array}{l}\text { Right inferior } \\
\text { frontal gyrus }\end{array}$ & $\begin{array}{l}1 \mathrm{~mA} / \\
20 \mathrm{~min}\end{array}$ & $\begin{array}{l}\text { Artificial grammar } \\
\text { learning and } \\
\text { grammatical decision }\end{array}$ & Online & $\begin{array}{l}\text { Left anodal tDCS improves } \\
\text { the overall performance in } \\
\text { the task of grammatical } \\
\text { decision }\end{array}$ & No follow-up \\
\hline Liuzzi et $a{ }^{43}$ & $\begin{array}{l}30 \text { (12 } \\
\text { men) } \\
27 \text { controls } \\
\text { (A) (12 } \\
\text { men) } \\
6 \text { controls } \\
\text { (B) (3 men) }\end{array}$ & $\begin{array}{l}24.97 \\
\pm 0.56 \\
24.96 \\
\pm 0.43 \\
24.50 \\
\pm 0.50\end{array}$ & $>12$ & $\mathrm{~A} / \mathrm{C} / \mathrm{S}$ & $5 \times 5$ & $\begin{array}{l}\text { Left motor } \\
\text { cortex }\end{array}$ & $\begin{array}{l}\text { Contralateral } \\
\text { supraorbital area }\end{array}$ & $\begin{array}{l}\text { Left dorsolateral } \\
\text { prefrontal cortex }\end{array}$ & $\begin{array}{l}1 \mathrm{~mA} / \\
20 \mathrm{~min}\end{array}$ & $\begin{array}{l}\text { Action/objects word } \\
\text { learning paradigm }\end{array}$ & Offline & $\begin{array}{l}\text { Cathodal tDCS on left motor } \\
\text { cortex reduces success rates } \\
\text { in action words vocabulary }\end{array}$ & $\begin{array}{l}7,14,28 \text { days } \\
\text { after tDCS }\end{array}$ \\
\hline Cattaneo et al ${ }^{44}$ & $\begin{array}{l}10 \text { ( } 4 \text { men) } \\
8 \text { controls } \\
\text { (3 men) }\end{array}$ & $\begin{array}{l}23.6 \pm 3.2 \\
23.8 \\
\pm 123.5\end{array}$ & $>12$ & $A / S$ & $5 \times 7$ & $\begin{array}{l}\text { Left inferior } \\
\text { frontal gyrus }\end{array}$ & $\begin{array}{l}\text { Contralateral } \\
\text { supraorbital area }\end{array}$ & $\begin{array}{l}\text { Right inferior } \\
\text { frontal gyrus }\end{array}$ & $\begin{array}{l}2 \mathrm{~mA} / \\
20 \mathrm{~min}\end{array}$ & $\begin{array}{l}\text { Verbal fluency } \\
\text { (phonemic and } \\
\text { semantic cue) }\end{array}$ & Offline & $\begin{array}{l}\text { Left tDCS improves verbal } \\
\text { fluency }\end{array}$ & No follow-up \\
\hline Holland et $a^{45}$ & 10 (3 men) & $69 \pm \mathrm{DNR}$ & DNR & $A / S$ & $5 \times 7$ & $\begin{array}{l}\text { Left inferior } \\
\text { frontal cortex }\end{array}$ & $\begin{array}{l}\text { Contralateral } \\
\text { frontopolar } \\
\text { cortex }\end{array}$ & No & $\begin{array}{l}2 \mathrm{~mA} / \\
20 \mathrm{~min}\end{array}$ & Picture naming & $\begin{array}{l}\text { Online and } \\
\text { during fMRI } \\
\text { study }\end{array}$ & $\begin{array}{l}\text { Anodal tDCS has significant } \\
\text { behavioural and regionally } \\
\text { specific neural facilitation } \\
\text { effect }\end{array}$ & No follow-up \\
\hline Wirth et $a{ }^{46}$ & $\begin{array}{l}20(10 \\
\text { men) }\end{array}$ & $23.5 \pm 3.7$ & $>12$ & $A / S$ & $5 \times 7$ & $\begin{array}{l}\text { Left dorsolateral } \\
\text { prefrontal cortex }\end{array}$ & Right shoulder & No & $\begin{array}{l}1.5 \mathrm{~mA} / \\
30 \mathrm{~min}\end{array}$ & $\begin{array}{l}\text { Semantic blocking } \\
\text { paradigm and } \\
\text { picture naming }\end{array}$ & $\begin{array}{l}\text { Online/ } \\
\text { offline } \\
\text { (EEG) }\end{array}$ & $\begin{array}{l}\text { Anodal tDCS is capable of } \\
\text { enhancing neural processes } \\
\text { during and after application }\end{array}$ & No follow-up \\
\hline \multicolumn{14}{|l|}{ Temporal tDCS } \\
\hline Sparing et $\left.a\right|^{47}$ & $\begin{array}{l}15(10 \\
\text { men) }\end{array}$ & $26.9 \pm 3.7$ & DNR & $\mathrm{A} / \mathrm{C} / \mathrm{S}$ & $5 \times 7$ & $\begin{array}{l}\text { Left posterior } \\
\text { perisylvian area }\end{array}$ & Vertex & $\begin{array}{l}\text { Right posterior } \\
\text { perisylvian area }\end{array}$ & $2 \mathrm{~mA} / 7 \mathrm{~min}$ & Picture naming & $\begin{array}{l}\text { Offline/ } \\
\text { online }\end{array}$ & $\begin{array}{l}\text { Left anodal tDCS reduces } \\
\text { latency of response }\end{array}$ & $\begin{array}{l}5 / 10 \text { min after } \\
\text { the end of } \\
\text { tDCS }\end{array}$ \\
\hline Floel et $a l^{48}$ & $\begin{array}{l}19(10 \\
\text { men) }\end{array}$ & $\begin{array}{l}25.36 \\
\pm 2.7\end{array}$ & DNR & $\mathrm{A} / \mathrm{C} / \mathrm{S}$ & $5 \times 7$ & $\begin{array}{l}\text { Left posterior } \\
\text { perisylvian area }\end{array}$ & $\begin{array}{l}\text { Contralateral } \\
\text { supraorbital area }\end{array}$ & No & $\begin{array}{l}1 \mathrm{~mA} / \\
20 \mathrm{~min}\end{array}$ & Verbal learning & Online & $\begin{array}{l}\text { Anodal tDCS facilitates } \\
\text { learning speed and accuracy }\end{array}$ & No follow-up \\
\hline Fiori et $a /^{49}$ & 10 (7 men) & $55 \pm 7.9$ & $>12$ & A/S & $5 \times 7$ & $\begin{array}{l}\text { Left posterior } \\
\text { perisylvian area }\end{array}$ & $\begin{array}{l}\text { Contralateral } \\
\text { fronto-polar } \\
\text { cortex }\end{array}$ & $\begin{array}{l}\text { Right } \\
\text { occipitoparietal } \\
\text { area }\end{array}$ & $\begin{array}{l}1 \mathrm{~mA} / \\
20 \mathrm{~min}\end{array}$ & $\begin{array}{l}\text { Associative verbal } \\
\text { learning }\end{array}$ & Online & $\begin{array}{l}\text { tDCS on left posterior } \\
\text { perisylvian area reduces } \\
\text { naming response latency }\end{array}$ & No follow-up \\
\hline Ross et $a l^{51}$ & 15 (4 men) & $\begin{array}{l}25.6 \\
\pm \mathrm{DNR}\end{array}$ & DNR & $A / S$ & $5 \times 7$ & $\begin{array}{l}\text { Left anterior } \\
\text { temporal lobe }\end{array}$ & $\begin{array}{l}\text { Contralateral } \\
\text { cheekbone }\end{array}$ & $\begin{array}{l}\text { Right anterior } \\
\text { temporal lobe }\end{array}$ & $\begin{array}{l}1.5 \mathrm{~mA} / \\
15 \mathrm{~min}\end{array}$ & $\begin{array}{l}\text { People and landmark } \\
\text { naming }\end{array}$ & Online & $\begin{array}{l}\text { Right tDCS increases } \\
\text { naming performance for } \\
\text { famous people }\end{array}$ & No follow-up \\
\hline
\end{tabular}

A, anodal tDCS; C, cathodal tDCS; DNR, data not reported; mA, milliampere; offline, the subject executes the task before and after stimulation; online, the subject executes the task during stimulation; S, sham tDCS; SD, standard deviation; tDCS, transcranial direct current stimulation. 
Table 2 tDCS studies on language functions in patients with aphasia

\begin{tabular}{|c|c|c|c|c|c|c|c|c|c|c|c|c|c|c|c|c|}
\hline $\begin{array}{l}\text { Studies on } \\
\text { aphasic } \\
\text { patients }\end{array}$ & Subjects & $\begin{array}{l}\text { Age } \\
\text { (mean } \\
\pm \text { SD } \\
\text { years) }\end{array}$ & $\begin{array}{l}\text { Education } \\
\text { years }\end{array}$ & $\begin{array}{l}\text { Time post } \\
\text { stroke in } \\
\text { months }\end{array}$ & $\begin{array}{l}\text { Type of } \\
\text { aphasia }\end{array}$ & Polarity & $\begin{array}{l}\text { Electrode } \\
\text { size }(\mathrm{cm})\end{array}$ & $\begin{array}{l}\text { Stimulated } \\
\text { areas }\end{array}$ & $\begin{array}{l}\text { Reference } \\
\text { electrode }\end{array}$ & $\begin{array}{l}\text { Control } \\
\text { areas }\end{array}$ & $\begin{array}{l}\text { Intensity/ } \\
\text { duration }\end{array}$ & Task & $\begin{array}{l}\text { Online/ } \\
\text { offline }\end{array}$ & $\begin{array}{l}\text { Concomitant } \\
\text { speech } \\
\text { rehabilitation }\end{array}$ & Effects & Follow-up \\
\hline \multicolumn{17}{|l|}{ Frontal tDCS } \\
\hline Monti et $a^{52}$ & $\begin{array}{l}8 \text { chronic } \\
\text { patients } \\
(4 \text { men) }\end{array}$ & $\begin{array}{l}60.37 \\
\pm 11.99\end{array}$ & $\geq 5$ & $\begin{array}{l}47.13 \\
\pm 22.89\end{array}$ & $\begin{array}{l}4 \text { Global } \\
4 \text { Broca's }\end{array}$ & $\mathrm{A} / \mathrm{C} / \mathrm{S}$ & $5 \times 7$ & $\begin{array}{l}\text { Left } \\
\text { frontotemporal } \\
\text { cortex }\end{array}$ & $\begin{array}{l}\text { Right } \\
\text { shoulder }\end{array}$ & $\begin{array}{l}\text { Left } \\
\text { occipital } \\
\text { cortex }\end{array}$ & $\begin{array}{l}2 \mathrm{~mA} \\
10 \mathrm{~min} / \\
\text { single } \\
\text { session }\end{array}$ & Picture naming & Offline & No & $\begin{array}{l}\text { Cathodal tDCS } \\
\text { improves } \\
\text { accuracy }\end{array}$ & No follow-up \\
\hline Hesse et $a F^{54}$ & $\begin{array}{l}10 \text { (5 with } \\
\text { aphasia) } \\
\text { sub-acute } \\
\text { patients } \\
(3 \text { men) }\end{array}$ & $\begin{array}{l}63.3 \\
\pm \text { DNR }\end{array}$ & DNR & $1-2$ & $\begin{array}{l}3 \text { Global } \\
2 \text { Wernike's }\end{array}$ & A & $5 \times 7$ & $\begin{array}{l}\text { Left motor } \\
\text { cortex }\end{array}$ & $\begin{array}{l}\text { Contralateral } \\
\text { supraorbital } \\
\text { area }\end{array}$ & $\begin{array}{l}\text { Right } \\
\text { motor } \\
\text { cortex }\end{array}$ & $\begin{array}{l}1.5 \mathrm{~mA} \\
7 \mathrm{~min} / 30 \\
\text { sessions }\end{array}$ & $\begin{array}{l}\text { Aachener } \\
\text { aphasia test }\end{array}$ & Online & Yes & $\begin{array}{l}\text { Anodal tDCS } \\
\text { improves } \\
\text { performance } \\
\text { testing for } 4 \\
\text { out of } 5 \\
\text { aphasics }\end{array}$ & No follow-up \\
\hline Baker et $a{ }^{55}$ & $\begin{array}{l}10 \text { chronic } \\
\text { patients } \\
\text { ( } 5 \text { men) }\end{array}$ & $\begin{array}{l}65.50 \\
\pm 11.44\end{array}$ & $\geq 12$ & $\begin{array}{l}64.60 \\
\pm 68.42\end{array}$ & $\begin{array}{l}6 \text { Anomic } \\
4 \text { Broca's } \\
\text { (plus AOS } \\
\text { in 5) }\end{array}$ & $A / S$ & $5 \times 5$ & $\begin{array}{l}\text { Left frontal } \\
\text { cortex }\end{array}$ & $\begin{array}{l}\text { Right } \\
\text { shoulder }\end{array}$ & No & $\begin{array}{l}1 \mathrm{~mA}, \\
20 \mathrm{~min} / 5 \\
\text { sessions }\end{array}$ & Picture naming & Online & Yes & $\begin{array}{l}\text { Anodal tDCS } \\
\text { increases } \\
\text { accuracy }\end{array}$ & $\begin{array}{l}1 \text { week } \\
\text { post-treatment } \\
\text { (the effect } \\
\text { persisted for } \\
1 \text { week after } \\
\text { treatment) }\end{array}$ \\
\hline $\begin{array}{l}\text { Marangolo } \\
\text { et } a^{56}\end{array}$ & $\begin{array}{l}3 \text { chronic } \\
\text { patients } \\
(2 \text { men) }\end{array}$ & $\begin{array}{l}66 \\
\pm 2.65\end{array}$ & $\geq 13$ & $\begin{array}{l}22.33 \\
\pm 22.67\end{array}$ & $\begin{array}{l}\text { Non-fluent } \\
\text { plus AOS }\end{array}$ & $A / S$ & $5 \times 7$ & $\begin{array}{l}\text { Left inferior } \\
\text { frontal cortex }\end{array}$ & $\begin{array}{l}\text { Contralateral } \\
\text { supraorbital } \\
\text { area }\end{array}$ & No & $\begin{array}{l}1 \mathrm{~mA}, \\
20 \mathrm{~min} / 5 \\
\text { sessions }\end{array}$ & $\begin{array}{l}\text { Syllables, } \\
\text { words } \\
\text { repetition }\end{array}$ & $\begin{array}{l}\text { Online } \\
\text { (20 min) }\end{array}$ & Yes & $\begin{array}{l}\text { tDCS increases } \\
\text { accuracy both } \\
\text { in sham and } \\
\text { anodal } \\
\text { condition, but } \\
\text { the effect } \\
\text { persists only } \\
\text { after anodal } \\
\text { condition. }\end{array}$ & $\begin{array}{l}1 \text { week, } \\
1 \text { month and } \\
2 \text { months } \\
\text { post-treatment } \\
\text { (generalisation } \\
\text { of the recovery } \\
\text { at language } \\
\text { examination } \\
\text { tests persists for } \\
2 \text { months after } \\
\text { treatment) }\end{array}$ \\
\hline Kang et $a l^{57}$ & $\begin{array}{l}10 \text { chronic } \\
\text { patients } \\
\text { (8 men) }\end{array}$ & $\begin{array}{l}61.9 \\
\pm 2.7\end{array}$ & $\geq 9$ & $52.4 \pm 21.9$ & $\begin{array}{l}3 \text { Global } \\
4 \text { Broca's } \\
2 \text { Anomic } \\
1 \text { Transcortical }\end{array}$ & C/S & $5 \times 5$ & $\begin{array}{l}\text { Right inferior } \\
\text { frontal gyrus }\end{array}$ & $\begin{array}{l}\text { Contralateral } \\
\text { supraorbital } \\
\text { area }\end{array}$ & No & $\begin{array}{l}2 \mathrm{~mA} \\
20 \mathrm{~min} / 5 \\
\text { sessions }\end{array}$ & Picture naming & Online & Yes & $\begin{array}{l}\text { Cathodal tDCS } \\
\text { increases } \\
\text { accuracy } 1 \mathrm{~h} \\
\text { following the } \\
\text { last session }\end{array}$ & No follow-up \\
\hline Vines et $a l^{58}$ & $\begin{array}{l}6 \text { chronic } \\
\text { patients } \\
(6 \text { men) }\end{array}$ & $\begin{array}{l}55.67 \\
\pm 16.16\end{array}$ & DNR & $\begin{array}{l}54.17 \\
\pm 38.03\end{array}$ & Broca's & A/S & $\begin{array}{l}4 \times 4(6 \times 5 \\
\text { reference) }\end{array}$ & $\begin{array}{l}\text { Right inferior } \\
\text { frontal gyrus }\end{array}$ & $\begin{array}{l}\text { Contralateral } \\
\text { supraorbital } \\
\text { area }\end{array}$ & No & $\begin{array}{l}1.2 \mathrm{~mA} \\
20 \mathrm{~min} / 3 \\
\text { sessions }\end{array}$ & $\begin{array}{l}\text { Automatic } \\
\text { speech, picture } \\
\text { description, } \\
\text { picture naming }\end{array}$ & $\begin{array}{l}\text { Online } \\
\text { (20 min) }\end{array}$ & Yes & $\begin{array}{l}\text { Anodal tDCS } \\
\text { improves } \\
\text { fluency of } \\
\text { speech }\end{array}$ & No follow-up \\
\hline Jung et $a l^{59}$ & $\begin{array}{l}37 \\
\text { sub-acute } \\
\text { and } \\
\text { chronic } \\
\text { patients } \\
\text { (26 men) }\end{array}$ & $\begin{array}{l}62.4 \\
\pm 12.9\end{array}$ & DNR & $\begin{array}{l}27 \\
\text { patients } \leq 3 \\
10 \\
\text { patients }>3\end{array}$ & $\begin{array}{l}10 \text { Fluent } \\
26 \text { Non fluent } \\
\text { (not specify) }\end{array}$ & C & $6 \times 6$ & $\begin{array}{l}\text { Right inferior } \\
\text { frontal gyrus }\end{array}$ & $\begin{array}{l}\text { Contralateral } \\
\text { supraorbital } \\
\text { area }\end{array}$ & No & $\begin{array}{l}1 \mathrm{~mA} \\
30 \mathrm{~min} / 10 \\
\text { sessions }\end{array}$ & $\begin{array}{l}\text { Korean } \\
\text { Western } \\
\text { version of } \\
\text { Western } \\
\text { aphasia } \\
\text { battery }\end{array}$ & Offline & Yes & $\begin{array}{l}\text { Cathodal tDCS } \\
\text { improves the } \\
\text { aphasia } \\
\text { quotient }\end{array}$ & No follow-up \\
\hline \multicolumn{17}{|l|}{ Temporal tDCS } \\
\hline Fiori et $a^{49}$ & $\begin{array}{l}3 \text { chronic } \\
\text { patients } \\
(3 \text { men })\end{array}$ & $\begin{array}{l}61.33 \\
\pm 14.84\end{array}$ & $\geq 13$ & $44 \pm 25.24$ & $\begin{array}{l}\text { Non fluent } \\
\text { (1 mild, } 1 \\
\text { moderate, } 1 \\
\text { severe) }\end{array}$ & A/S & $5 \times 7$ & $\begin{array}{l}\text { Left posterior } \\
\text { perisylvian area }\end{array}$ & $\begin{array}{l}\text { Contralateral } \\
\text { fronto-polar } \\
\text { cortex }\end{array}$ & No & $\begin{array}{l}1 \mathrm{~mA} \\
20 \mathrm{~min} / 5 \\
\text { sessions }\end{array}$ & Picture naming & Online & Yes & $\begin{array}{l}\text { Anodal tDCS } \\
\text { increases } \\
\text { accuracy }\end{array}$ & $\begin{array}{l}1 \text { and } 3 \text { weeks } \\
\text { post-treatment } \\
\text { (the effect } \\
\text { persists for } \\
3 \text { weeks after } \\
\text { treatment) }\end{array}$ \\
\hline
\end{tabular}




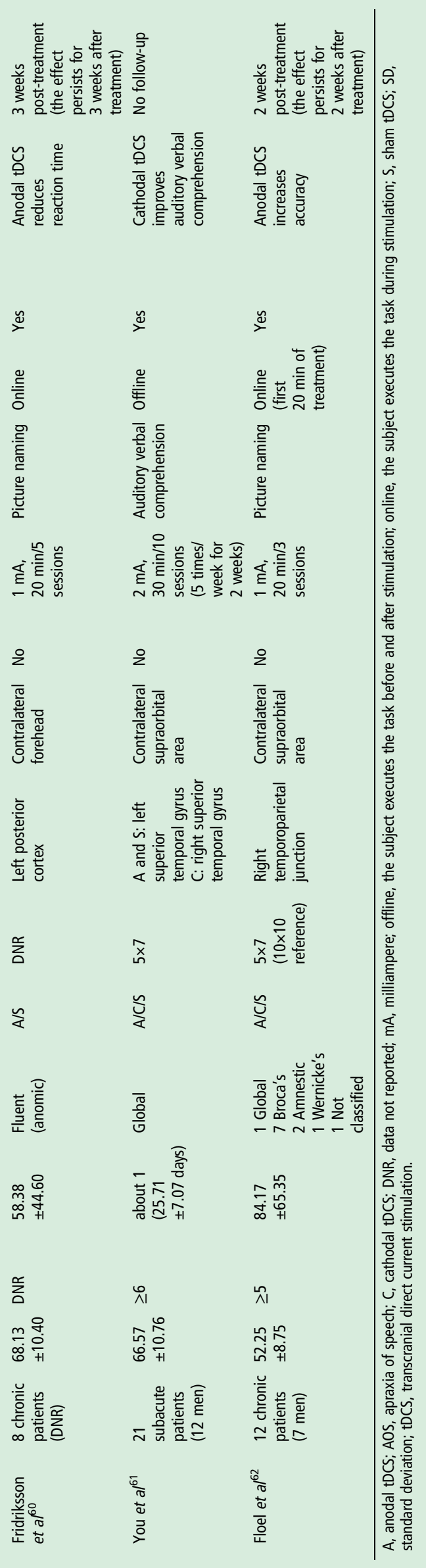

and depression. ${ }^{29} 30$ Pharmacological studies in healthy individuals showed that using a NMDA-receptor antagonist, the aftereffect of tDCS was abolished and that other drugs acting on neuronal transmitters (ie, GABAergic, dopaminergic, cholinergic) can alter the tDCS after-effect. ${ }^{20}$ Apart from the effects on neurotransmitters, direct currents could also change the proteic synthesis, ${ }^{31}$ calcium neuronal influx, ${ }^{32} 33$ the shape of cytoskeleton, ${ }^{34}$ blood flow, the level of brain oxygenation ${ }^{35}$ and locally the $\mathrm{pH}^{21}$

The neurophysiological effects induced by tDCS on cortical excitability can, however, differ between normal and damaged cerebral cortex. Suzuki and colleagues ${ }^{36}$ reported that whereas anodal tDCS increased the size of motor-evoked potentials (MEPs in muscles in the affected hand in patients and in normal subjects, cathodal tDCS increased MEP evoked from the affected hemisphere in patients with stroke but decreased the-MEPs in normal subjects. In addition, in patients with stroke both anodal and cathodal tDCS increased the excitability of the damaged motor cortex. Suzuki and colleagues ${ }^{36}$ therefore provide evidence that tDCS effects differ between patients with stroke and healthy subjects.

Despite the differences of responses to tDCS between normal and damaged cerebral cortex in stroke patients, direct currents definitely induce prolonged excitability and functional changes in the brain. This is the reason for using tDCS in restorative neurology. ${ }^{14}$

As a neuromodulating technique for therapeutic use, tDCS seems to be preferable to TMS for several reasons. tDCS is less expensive than TMS, easier to use and can be delivered via a portable system. Placebo or 'sham' stimulation is more reliable in tDCS than in TMS because patients rarely perceive active tDCS while the TMS coil emits a loud click for each stimulus delivered. $^{37} 38$ Because TMS induces electric current in the scalp as well as the brain, it usually activates local sensory nerves or muscles thus causing a sensation that patients can readily perceive. TMS and tDCS are also different in terms of spatial resolution of stimulation. The low focality of tDCS can represent a further advantage over TMS because large brain areas are targeted when tDCS is applied for therapeutic purposes (for instance motor cortex in post-stroke rehabilitation) without using expensive and time-consuming targeting procedures required for TMS (neuronavigation). Finally, because electrodes are easily secured to the scalp and leave the patient free to move, $\mathrm{tDCS}$ can be delivered while patients engage in a task or during rehabilitation (online stimulation). ${ }^{38}$ In essence, tDCS can be done during almost any human activity (except, possibly, swimming).

\section{tDCS STUDIES IN NORMAL LANGUAGE tDCS over the frontal cortex}

In a study designed to evaluate the safety of delivering direct current stimulation to the left prefrontal lobe, Iyer and colleagues $^{39}$ assessed the effects induced by tDCS testing global measures of processing and psychomotor speed, emotion and verbal fluency, in a parallel design study. They found that after anodal tDCS performance on a letter cue-word generation task improved significantly. Conversely, after cathodal tDCS verbal fluency decreased slightly. Because the tDCS-induced changes in language task performance became evident only at $2 \mathrm{~mA}$ they depended on stimulation intensity. Their conclusion agrees with neurophysiological studies applying tDCS to the cortical motor areas showing that the magnitude and direction of the induced excitability changes depend on the stimulus variables used. ${ }^{40}$ 


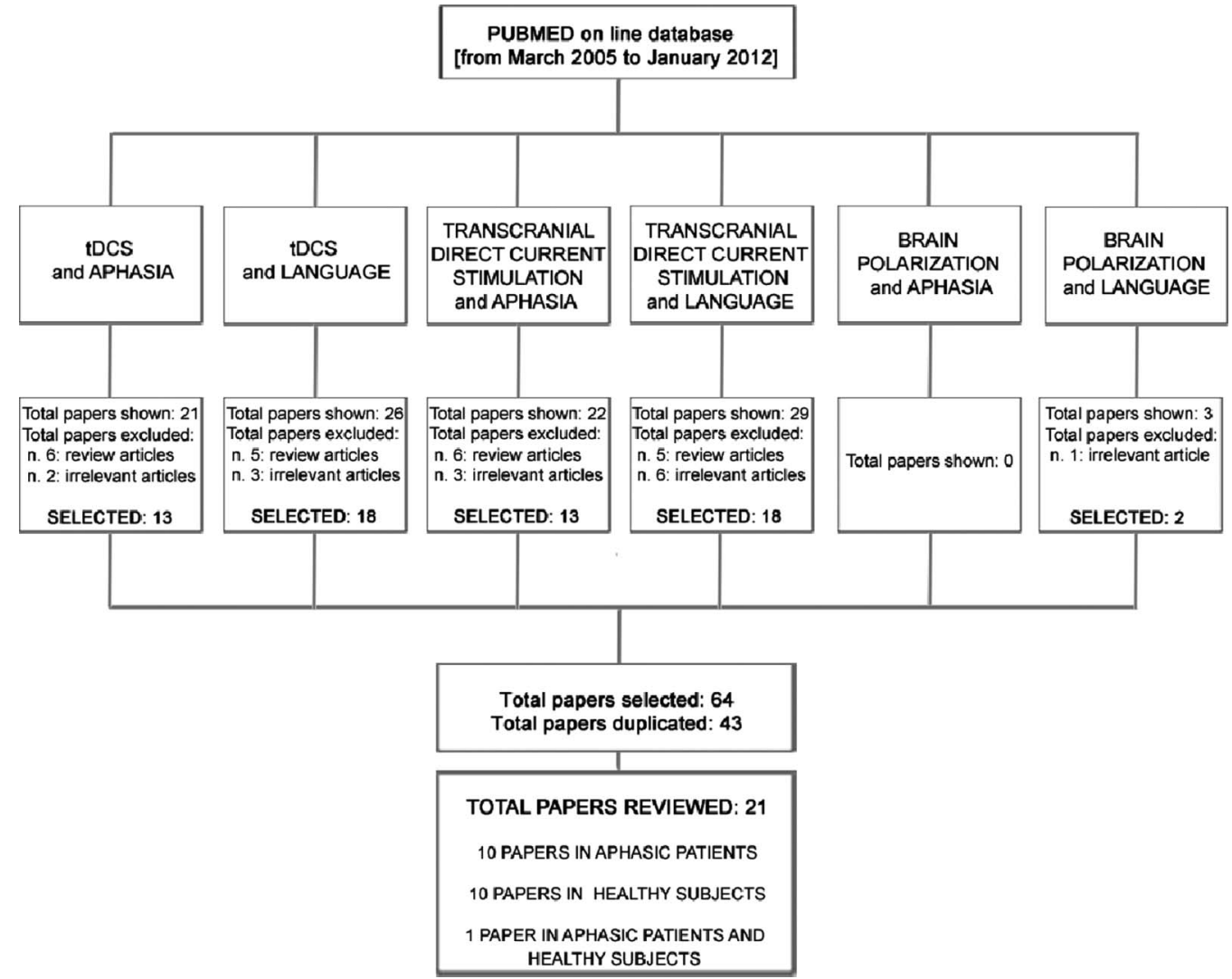

Figure 1 The flowchart shows the criteria and key word search terms used to select papers from the PUBMED database. Twenty-one studies were selected, 10 for aphasic patients, 10 for healthy subjects and one study reported data from healthy subjects and patients. ${ }^{49}$ Irrelevant articles include papers on other pathologies, or using different techniques, or investigating functions different from language or are predictions based on computational models. tDCS, transcranial direct current stimulation.

In a study designed to explore how tDCS influences language networks, Fertonani and colleagues ${ }^{41}$ found that anodal stimulation on the left dorsolateral prefrontal cortex improves naming performance, speeding up verbal reaction times, whereas cathodal stimulation had no effect. By administering an attentive task they excluded non-specific effects due to a general increase in arousal. The authors concluded that the left dorsolateral prefrontal cortex belongs to the cerebral network dedicated to lexical retrieval/selection processing in naming. ${ }^{41}$

De Vries and colleagues ${ }^{42}$ investigated with tDCS the functional role of Broca's area (left hemisphere) in syntactic processing, by an artificial grammar learning paradigm testing the ability to learn invented but syntactically structured language. Whereas in the acquisition phase grammar learning performance was comparable between groups, in the classification phase accuracy improved significantly more during anodal than during sham tDCS. Before participating in the experiment the subjects were assessed for general intellectual performance, working memory and attention, they underwent blood pressure measurement before and after the experimental session, and their performance was assessed on the positive and negative affective schedule, a self-report measure of positive and negative affect. No group differences were found in cognitive tests at baseline, either in blood pressure, heart rate and positive and negative affective schedule ratings at baseline and after the experimental session. The most important finding in this study was that tDCS can improve syntactic violation detection, an advantage of potential interest for language rehabilitation in some patients with aphasia, who can often no longer use the grammatical rules successfully. In an additional group enrolled for a control experiment, stimulating the right inferior frontal gyrus, an area that has not been implicated in artificial grammar learning tasks, similar results were found in the tDCS and sham groups, thus arguing for a topographic specificity for the improvement of syntactic violation detection.

To investigate how tDCS influences associative learning of novel action-related words, Liuzzi and colleagues ${ }^{43}$ tested whether interference with plasticity-related motor cortical mechanisms influenced an associative learning paradigm. They applied cathodal, anodal and sham tDCS to the left motor cortex in young healthy volunteers who then engaged in a language-learning paradigm. Cathodal tDCS reduced success rates in vocabulary acquisition, no such effect was observed after anodal or sham stimulation. When the investigators presented two control conditions applying tDCS over the prefrontal cortex and also tested learning of object-related words, they found no comparable effects, supporting the topographic and semantic specificity of the effect observed after left motor cortex stimulation. The study provides direct evidence showing that the left motor cortex is involved in the acquisition of novel action-related words.

Another key language performance test commonly used in clinical practice to investigate speech production is verbal fluency. Cattaneo and colleagues ${ }^{44}$ investigated anodal tDCS-induced changes in verbal fluency tasks. The study is the first that assessed both letter and category cue-word generation. When they applied anodal tDCS over Broca's region (left hemisphere) semantic and phonemic fluency both improved, but 
when they stimulated the right homologue hemisphere fluency scores remained unchanged (figure $2 \mathrm{~A}$ ). The investigators concluded that verbal fluency depends critically on the left Broca's region and tDCS studies designed to enhance language functions in patients with oral language production deficits should target the left Broca's area 44/45. A control task in seven participants showing that real and sham tDCS over Broca's region elicited similar response latencies in a spatial attention task excluded the possibility that the observed language changes depended on arousal or attention. Although some participants may have been aware of the difference between real and sham tDCS, Cattaneo and colleagues ${ }^{44}$ showed that this possible knowledge had no effect on language performance.

Seeking information on another language skill that is often impaired in patients with aphasia, Holland and colleagues ${ }^{45}$ tested the effects of anodal tDCS over the left inferior frontal cortex on spoken picture-naming performance in 10 adults, in

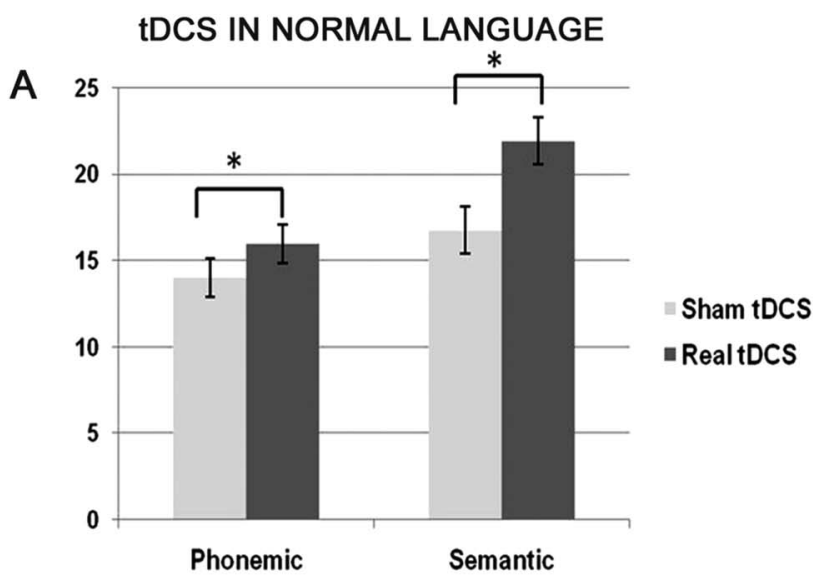

B

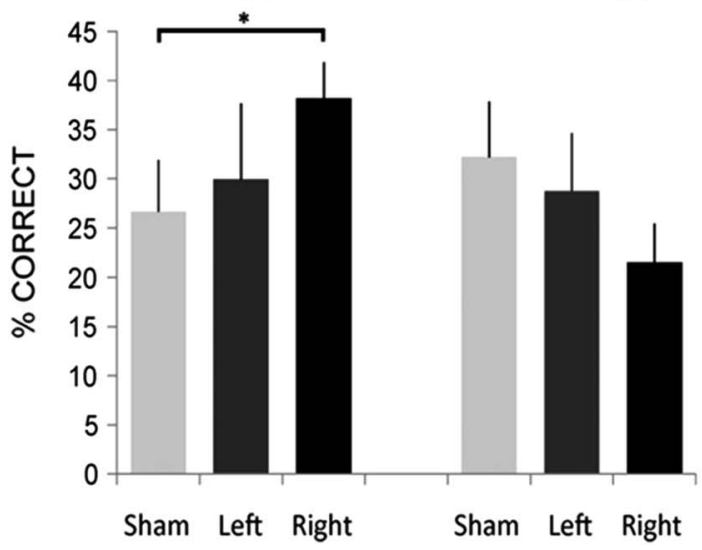

Figure 2 Results obtained with frontal and temporal transcranial direct current stimulation (tDCS) in language tasks in healthy subjects. (A) Anodal tDCS, but not sham, applied over Broca's region increased phonemic and semantic fluency in 10 healthy subjects. $Y$ axis: mean number of words. *Significant different error bars are standard error of the mean (SEM) (from Cattaneo et al, ${ }^{44}$ with permission). (B) Anodal tDCS over the right anterior temporal lobe significantly improved naming for people but not landmarks in 15 healthy subjects. $Y$ axis: average percent accuracy for correct trials with long response times $(>5 \mathrm{~s})$ in the face condition and place condition. Note that face naming accuracy increased by $11 \%$, from $27 \%$ in the sham condition to $38 \%$ after anodal tDCS to the right anterior temporal lobe. *Significant difference. Error bars are not reported (from Ross et al, ${ }_{1}^{51}$ with permission). an age range matching that for stroke patients. The researchers combined left frontal anodal tDCS during an overt picturenaming with functional MRI (fMRI). Anodal tDCS induced a significant improvement in naming response times. Anodal tDCS also reduced fMRI blood-oxygen level-dependent signals in the left frontal cortex, including Broca's area. tDCS had significant behavioural and regionally specific blood oxygenation effects in the brain, supporting the importance of Broca's area in the naming network and pointing to this area as a candidate site for anodal tDCS in rehabilitation protocols aiming to improve anomia in patients whose brain damage spares this region. The investigators underline that combining tDCS, fMRI, and behavioural measurement could provide a more informative and complete insight into the specific brain activation induced by tDCS.

In a combined EEG-tDCS study, Wirth and colleagues 46 traced the effects of tDCS over the left dorsal prefrontal cortex testing electrophysiological and behavioural variables during overt picture naming. The investigators used the semantic blocking paradigm in which lexical-semantic competition increases when subjects have to name pictures of objects displayed in a semantically homogeneous context (ie, cherries among grapes, pears and oranges) and decreases when the target object appears among semantically unrelated objects (heterogeneous blocks containing for example, cherries among flies, a cocktail and a bed). Anodal tDCS induced modulations of behavioural and electrophysiological data. The authors concluded that electrophysiological variables could help to understand how prefrontal anodal tDCS influences language production.

\section{tDCS over the temporal cortex}

Sparing and colleagues ${ }^{47}$ investigated anodal tDCS over the left posterior perisylvian area, they showed that after tDCS response latencies decreased (the effect disappeared 5 or 10 min after tDCS ended). These results suggest that stimulating the left posterior perisylvian area (including Wernicke's area and Broca's area 22) improves naming whereas stimulating the right homologous area does not.

Based on the assumption that verbal learning ability is crucial for acquiring new languages in healthy individuals and for language reacquisition after brain lesions, Floel and colleagues ${ }^{48}$ stimulated Wernicke's area in a crossover design during a task involving learning a new lexicon. Learning speed and overall accuracy increased with anodal tDCS. Anodal tDCS improved performance significantly more than cathodal and sham tDCS did, whereas it left mood, reaction times and style of response unchanged. These findings suggest that tDCS, combined with intensive training, can facilitate verbal learning and could therefore improve language recovery in patients.

In a later study, using different language tasks in both healthy subjects and patients with aphasia, Fiori and colleagues ${ }^{49}$ obtained comparable results despite studying differing age ranges. After subjects learned new 'words' arbitrarily assigned to 20 different pictures, the authors applied tDCS over Wernicke's area during word retrieval. Naming latencies were shorter during left anodal tDCS than during sham tDCS. These data suggest that the temporal region intervenes specifically when subjects activate phonological word representation in the late stages of lexical access.

Recalling proper names is a complex process involving several information processing steps and a wide brain network. ${ }^{50}$ In a study enrolling healthy subjects, Ross and colleagues ${ }^{51}$ investigated how tDCS influences naming famous people and places. When the items were known but the name was difficult to recall 
tDCS over the right anterior temporal lobe helped to increase accuracy in naming famous people but had no effect on accuracy in the landmarks condition (figure 2B). Showing a selective accuracy effect for famous people, the investigators underlined that the right anterior temporal lobe plays a prominent role in proper naming of social stimuli.

In conclusion, although the encouraging effects induced by tDCS on language in healthy individuals provide an overall rationale for using tDCS for rehabilitation in patients with aphasia, the complex language networks involved and the numerous tasks used for assessing language production and comprehension make it difficult to compare the various results. Another problem is that because methodological factors such as study protocol characteristics, duration of stimulation, electrode size and inter-electrode distance influence tDCS-induced changes in language networks, the tDCS benefits on language vary. Some studies did not provide information on topographic specificity by stimulating a control area. ${ }^{39} 41454648$ Not all the studies we reviewed specify the education level, an important neurolinguistic variable. ${ }^{41} 454748$ Future tDCS studies should also recruit older healthy individuals to take into account age-related tissue changes that could interfere with tDCS language effects. In conclusion, despite some limitation, altogether these studies in normal subjects provide evidence of a tDCS-induced effect on language that is topographic and function specific.

\section{tDCS STUDIES IN APHASIA}

The first investigators who specifically sought to clarify the effects of tDCS in patients with aphasia were Monti and colleagues. ${ }^{52}$ They applied tDCS over damaged left frontotemporal areas in non-fluent patients with chronic aphasia and evaluated the effect of anodal, cathodal and sham stimulation. Patients were tested before and immediately after tDCS with a picturenaming task. After cathodal stimulation accuracy in naming abilities improved by $33.6 \%$ (figure 3A). The other conditions (anodal and sham tDCS) failed to improve naming abilities nor did cathodal tDCS to the occipital area facilitate the naming task. Therefore, the improvement in naming after cathodal tDCS over the left frontotemporal areas was polarity and site specific. Because cathodal tDCS decreases excitability in cortical inhibitory circuits, ${ }^{53}$ the improvement could reflect tDCSinduced cortical inhibitory interneuron depression, ultimately leading to disinhibition and, consequently, improving function in the damaged language areas of the cerebral cortex. In line with this hypothesis, Suzuki and colleagues ${ }^{36}$ found that cathodal tDCS increased the excitability of the damaged cortex in patients with stroke. Whatever the mechanism, this first pilot report opened the way to studies investigating how tDCS can be used to improve language in patients. The investigators suggested that tDCS applied daily could induce an even greater language improvement, and recommended further studies especially to find out how this technique combined with speech rehabilitation could be used to treat non-fluent post-stroke aphasia. $^{52}$

\section{tDCS over the frontal cortex}

In a study conducted to verify the effect of anodal tDCS applied to the motor cortex during physical therapy in patients with upper limb paresis, Hesse and colleagues ${ }^{54}$ collaterally and incidentally reported a language improvement at least in one to four of the five subtests of the Aachener aphasia test in four out of five patients with aphasia. The changes induced by motor cortex stimulation on language functions could depend on the
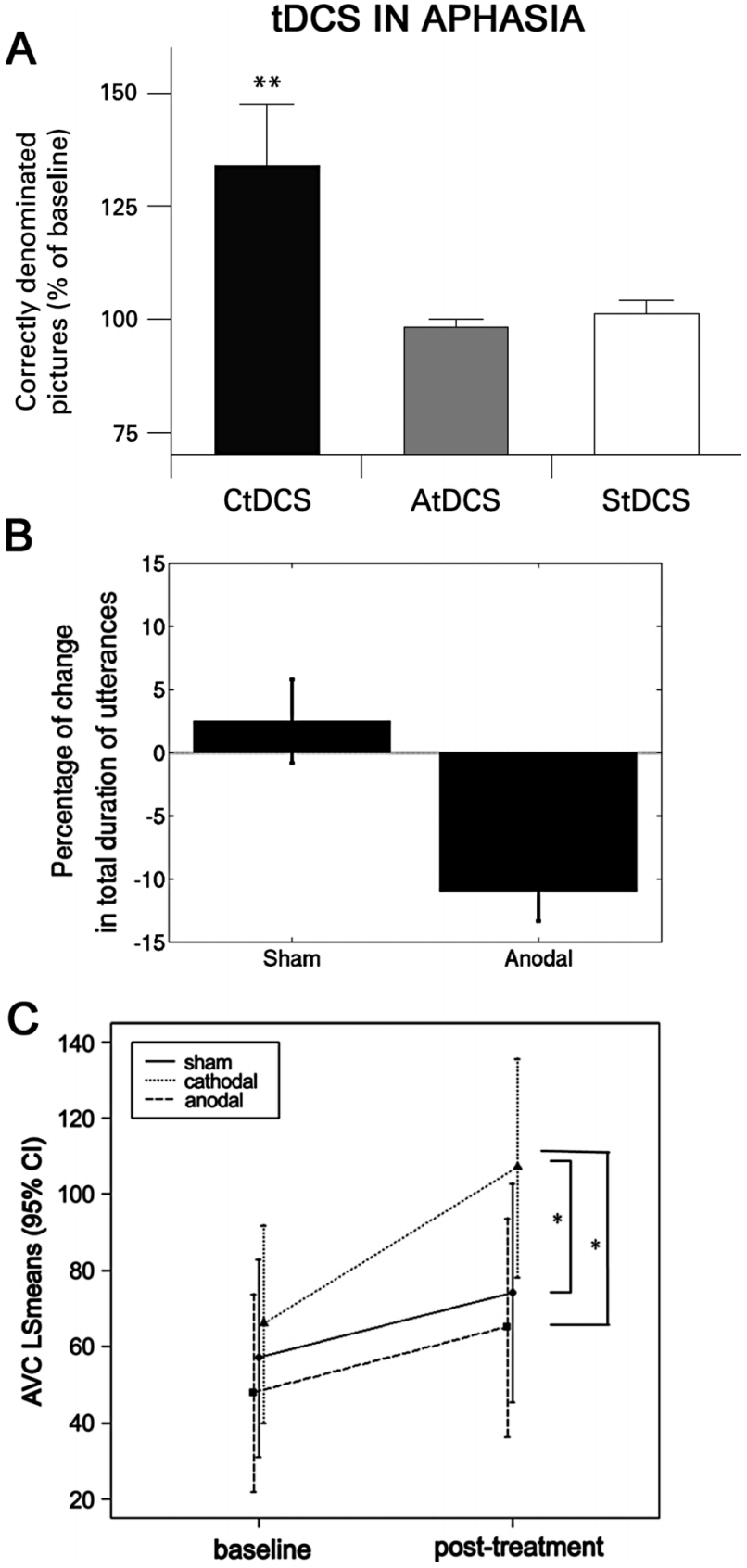

Figure 3 Results obtained with frontal and temporal transcranial direct current stimulation (tDCS) in language tasks in aphasic patients. (A) Cathodal tDCS over the left frontotemporal area significantly improved accuracy in the picture naming task in eight aphasic patients. $Y$ axis: naming accuracy expressed by percentage variation from baseline. **Significant difference error bars are standard error of the mean (SEM). AtDCS, anodal tDCS; CtDCS, cathodal tDCS; StDCS, sham tDCS (from Monti et al, ${ }^{52}$ with permission). (B) Anodal tDCS applied over the right inferior frontal gyrus significantly decreased the total duration of utterances, the language variable that signifies an improvement in verbal fluency, in six patients with Broca's aphasia. Error bars are SEM (from Vines et $a l_{1}^{58}$ with permission). (C) Cathodal tDCS over the right superior temporal gyrus significantly improved auditory-verbal comprehension in 21 patients. $Y$ axis: auditory-verbal comprehension least squares means scores. * Significance difference error bars are the interval of confidence $(\mathrm{Cl})$. AVC, auditory verbal comprehension; LS, least squares (from You et al, ${ }^{61}$ with permission).

anatomical contiguity between the hand motor area and language areas. These results could be strengthened by a larger study sample, sham stimulation and control area stimulation. 
Another study with left frontal cortex tDCS was conducted by Baker and colleagues ${ }^{55}$ in a group of patients with chronic aphasia who received anodal tDCS and sham tDCS during computerised treatment for anomia. To ensure that the active electrode was placed over the structurally intact left frontal cortex, electrodes were positioned in each subject according to data from a previous fMRI study. After anodal tDCS, naming accuracy improved significantly and the benefit lasted 1 week after treatment ended. Even though this study showed promising results in patients with fluent and non-fluent aphasia, and used a well-designed method, because several patients scored well in tests for naming accuracy, a further outcome variable might be response time.

A recent study conducted by Marangolo and colleagues ${ }^{56}$ showed the positive effects of anodal tDCS over the left inferior frontal gyrus in daily sessions, in a small sample of chronic patients with apraxia of speech after stroke. In all patients, anodal tDCS stimulation helped patients to recover from their articulatory disturbances. Response accuracy improved more after anodal than after sham tDCS. Follow-up testing showed that the improvement in response accuracy persisted only for the anodal condition, up to 2 months after treatment. The investigators suggest that in aphasic patients, anodal tDCS applied over the inferior frontal gyrus together with simultaneous language training improves articulatory performance. Despite the small study sample and the lack of stimulation on a control area, this is the first report that has explored tDCS as a therapy for articulatory disturbances and monitored treatment effect over time. ${ }^{56}$

In a study enrolling a group of patients with chronic aphasia, Kang and colleagues ${ }^{57}$ applied tDCS on the Broca's homologue area, under two experimental conditions: patients first received word retrieval training alone followed by word retrieval training plus cathodal tDCS or sham tDCS. After cathodal tDCS plus training, naming accuracy improved significantly from baseline. Pre and post-performance differed more after cathodal tDCS than after sham. No significant differences were found for reaction times and percentage of cued responses, even though both variables tended to diminish after cathodal tDCS. The investigators concluded that cathodal tDCS over the right Broca's homologue area improves accuracy. Cathodal tDCS induced the greatest improvement in the two patients with the most severe aphasia, both of whom received cathodal tDCS first and were treated early after stroke onset.

Again using tDCS combined with speech therapy to treat aphasia, Vines and colleagues ${ }^{58}$ reported that anodal tDCS applied over the right inferior frontal gyrus and simultaneous melodic intonation therapy (MIT) improved speech fluency. Patients with chronic moderate-to-severe Broca's aphasia received two treatment series (anodal tDCS/sham plus MIT) that were administered randomly and separated by 1 week. Even though the study sample was small, and lacked a control stimulation area and follow-up, the results provided evidence that applying anodal tDCS to the right inferior frontal gyrus during MIT can augment the beneficial effects induced by intonationbased speech therapy alone (figure 3B).

Jung and colleagues ${ }^{59}$ aimed to determine which factors are associated with good responses to tDCS combined with speech therapy in patients with subacute and chronic aphasia after stroke. As a task they used the Korean version of the Western aphasia battery, a test that gives a summary score, the aphasia quotient percentage indicating overall severity of language deficits. Factors such as age, sex, initial treatment time after stroke, types of stroke, and type of aphasia were considered as variables associated with good responses. Patients received speech therapy during cathodal tDCS over the right inferior frontal gyrus, significantly improving the aphasia quotient percentage. This improvement was more evident in patients with less severe, fluent aphasia who received treatment earlier than 30 days after stroke developed. Patients with haemorrhagic stroke were more likely than those with infarction to achieve good responses. The improvement was not significantly associated with age and sex. Although considering the possible role of several factors in improving the use of tDCS in aphasia is of great interest, the study has several limitations. For example, initial evaluation time varied among patients, no control group was included, no sham stimulation was tested and no follow-up was reported.

\section{tDCS over temporal cortex}

Fiori and colleagues ${ }^{49}$ also investigated the potential of tDCS to improve word retrieval deficits in a small sample of patients with stroke-induced aphasia. They applied left temporal tDCS in a randomised double-blind experiment involving intensive language training for anomia in aphasic patients. Each patient participated in five consecutive daily sessions testing anodal tDCS and sham stimulation over Wernicke's area during a picture-naming task. When the sessions ended, accuracy on the picture-naming task had significantly improved and patients responded faster in the anodal than in the sham condition. At follow-up visits, attended by only two aphasic patients, response accuracy and response times were still significantly better in the anodal than in the sham condition, suggesting, despite the small sample size, that the effect on recovery of anomic disturbances persisted at least 3 weeks after treatment.

Continuing their research focused on the pathophysiology of aphasia recovery in stroke and speech processing in normal individuals, Fridriksson and colleagues ${ }^{60}$ examined the effect of left temporal anodal tDCS on reaction times during overt picture naming in chronic stroke patients. Anode electrode placement targeted perilesional brain regions that showed the greatest activation on a pretreatment fMRI scan acquired during overt picture naming. Coupling anodal tDCS with behavioural language treatment for five sessions reduced reaction times during the naming of trained items immediately post treatment and the effect persisted at 3 weeks after treatment ended. The study is particularly interesting because clinicians were blind to stimulation types, a broad range of aphasia types and lesion sites were included, and follow-up lasted 3 weeks.

Another study conducted by You and colleagues ${ }^{61}$ was designed to examine the effects of tDCS over the temporal lobe on auditory verbal comprehension in patients with subacute global aphasia. During tDCS patients received conventional speech and language therapy. Before and after tDCS patients were administered the Korean version of the Western aphasia battery (which gives four subtest scores: spontaneous speech, auditory verbal comprehension, repetition and naming). Auditory verbal comprehension improved more after cathodal tDCS than after anodal or sham stimulation over the left superior temporal areas in patients with subacute global aphasia (figure 3C). Although the study lacks the stimulation of a control area and a follow-up session, it suggests that tDCS could be useful even early after stroke.

Others applied tDCS over the right homologue temporal area. For example, Floel and colleagues ${ }^{62}$ administered anodal, cathodal and sham tDCS over the right temporoparietal cortex in patients with chronic aphasia after a stroke. Whereas anodal tDCS applied over the non-language dominant hemisphere significantly improved language training outcome (from 0 to a 
A

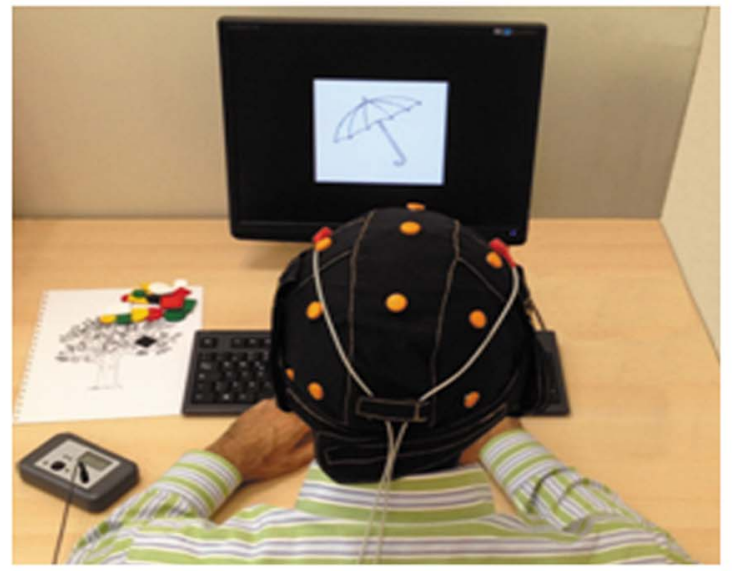

HEALTHY SUBJECTS

B

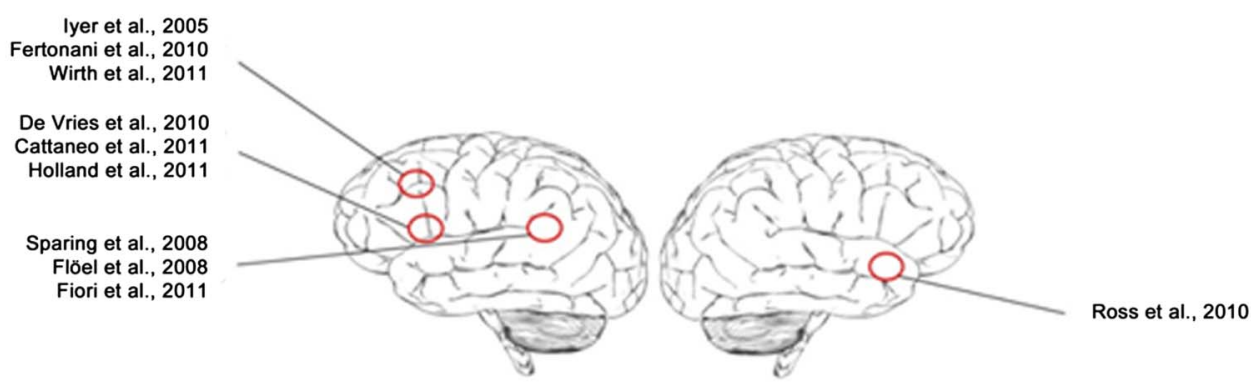

APHASIC PATIENTS

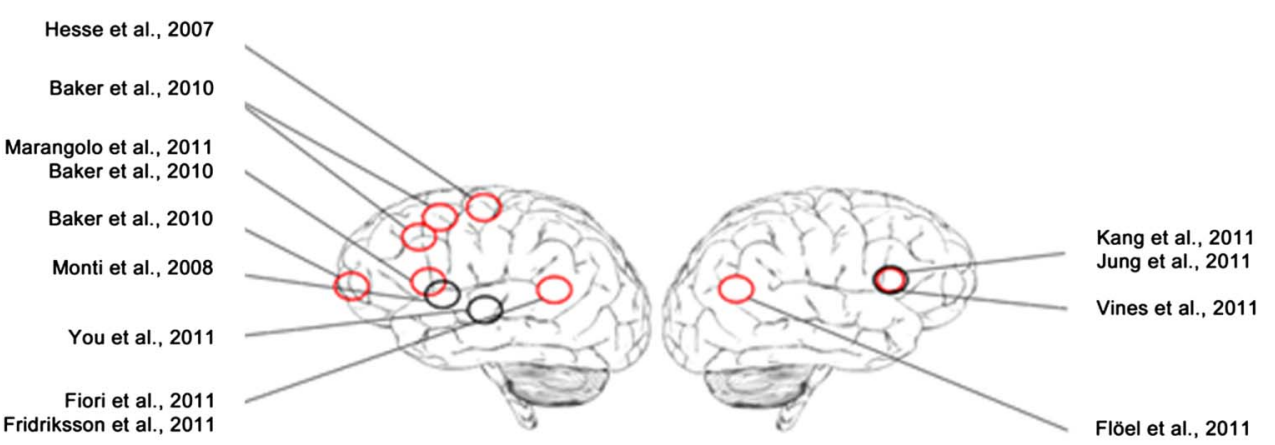

\section{Left hemisphere}

\section{Right hemisphere}

Figure 4 (A) A patient with aphasia during an experimental session with transcranial direct current stimulation (tDCS): the anodal electrode is placed over the (left) perilesional area and the cathodal over the contralateral hemisphere. tDCS is delivered during speech therapy through a special stimulating cap that allows a simple positioning of electrodes. (B) Schematic diagrams of brain locations where tDCS improved language in normal subjects (top) and in aphasic patients (bottom). Red circles represent anodal stimulation and black circles cathodal stimulation (active electrodes). Note, however, that the position of the reference electrode differed across different studies. This figure is only reproduced in colour in the online version and red circles are grey in the printed version.

mean of $83 \%$ correct responses after training) and this effect persisted 2 weeks after the treatment, cathodal tDCS resulted in a weaker and less consistent improvement. Poorer naming performance before treatment was associated with more pronounced improvement only in the anodal condition, but no association was found between treatment success and age, or education, or time post-onset or lesion sites. 
approximately $25 \%$ in speech performance in aphasic patients. Intriguingly, no report described negative results in aphasic patients. Although tDCS-induced benefits in language might partly depend on improved learning ${ }^{64}$ or working-memory ${ }^{65}$ tDCS could improve activation in lesioned and vicarious cortical speech areas and reduce activation in competing homologous contralateral cortical areas, ${ }^{49}$ 54-56 60 ultimately improving language.

There are also several general critical issues to consider. Most studies have a limited follow-up and provide scarce information about how long the tDCS-induced language benefits persist. In addition, although most studies involved chronic patients-thus reducing potential bias from spontaneous recovery-only two reports referred to subacute cases-another possible time window for effective tDCS treatment. tDCS research should also systematically consider the type of stroke (ischaemic vs haemorrhagic), per se an important clinical variable for aphasia recovery. A final point is whether the tDCS-induced improvement in language variables is ecologically relevant for patients and their caregivers.

Again, despite the wide heterogeneity in the data available for review, we try to offer some practical operative suggestions for those wishing to approach tDCS to treat patients with aphasia. Although opposite tDCS polarities appear both to increase the excitability of the cerebral cortex damaged by stroke, where the stimulating electrodes have to be placed is an important issue. Whereas anodal tDCS improves language over the perilesional areas, 49555660 cathodal tDCS seems to be effective over the lesioned cortex $^{52}$ or on the contralateral hemisphere. ${ }^{57} 5961$ Therefore, placing the anodal electrode over the perilesional area with the cathodal over the contralateral hemisphere could, theoretically, boost tDCS-induced language improvement. The second suggestion concerns stimulation duration and intensity. The optimal repetition rate and duration to promote tDCS-induced plasticity also remains to be determined. A reasonable choice might be 1-2 $\mathrm{mA}$ for $20 \mathrm{~min}$ using common electrode sizes of $35 \mathrm{~cm}^{2}$ (generating change densities ranging from 0.034 to $0.068 \mathrm{C} / \mathrm{cm}^{2}$ ) in repeated daily sessions (35 days). Finally, because most available data on tDCS-induced language improvement concern patients with anomia, these patients seem the most likely to respond.

\section{FUTURE DIRECTIONS}

Although the clinical efficacy of tDCS in aphasia awaits confirmation in large, randomised controlled clinical studies, future research work should systematically assess the clinical patients' features predicting an optimal response. The possible therapeutic effectiveness of tDCS could also depend on several factors including type and site of lesion, time elapsing after the lesion, age, gender, concurrent treatments (including repetitive TMS) and comorbidities. A further major research effort should aim also to identify the optimal stimulation parameters (site, electrode montage and size, duration, intensity, number of sessions, online vs offline, duration of treatment) possibly for the specific types of aphasia and individual patients. For instance, given that a recent study in major depression ${ }^{66}$ concluded that treatment should be continued for several weeks to achieve the optimal clinical response, the same might apply to aphasic patients.

Despite the uncertainties, thanks to its simplicity, low cost, and suitability for use online tDCS holds great promise in the field of restorative neurology and rehabilitation. ${ }^{9}$ This potential must, however, be developed through strictly controlled and methodologically sound experimental and clinical research work. ${ }^{19}$
Contributors AM, RF, MF, FM, FC, GA and AP: drafting the article and revising it critically for important intellectual content. All the authors contributed equally, have seen and approved the final version of the manuscript taking the full responsibility for its content.

Competing interests $A M, M F$ and GA have no financial interest. FC, RF, FM and AP are stakeholders in Newronika s.r.l., a spin-off company of the Fondazione IRCCS Ca' Granda Ospedale Maggiore Policlinico and the Università degli Studi di Milano.

Provenance and peer review Not commissioned; externally peer reviewed.

Open Access This is an Open Access article distributed in accordance with the Creative Commons Attribution Non Commercial (CC BY-NC 3.0) license, which permits others to distribute, remix, adapt, build upon this work non-commercially, and license their derivative works on different terms, provided the original work is properly cited and the use is non-commercial. See: http://creativecommons.org/licenses/by-nc/3.0/

\section{REFERENCES}

1 Chomsky N. Language and mind. New York: Harcourt, Brace \& World, 1968.

2 Saur D, Hartwigsen G. Neurobiology of language recovery after stroke: lessons from neuroimaging studies. Arch Phys Med Rehabil 2012;93:S15-25.

3 Penfield W. Conditioning the uncommitted cortex for language learning. Brain 1965:88:787-98.

4 Ojemann GA. Brain organization for language from the perspective of electrical stimulation mapping. Behav Brain Sci 1983;6:189-230.

5 Ojemann GA. Functional mapping of cortical language areas in adults. Intraoperative approaches. Adv Neurol 1993;63:155-63.

6 Rapport RL, Tan CT, Whitaker HA. Language function and dysfunction among Chinese- and English-speaking polyglots: cortical stimulation, Wada testing, and clinical studies. Brain Lang 1983:18:342-66.

7 Hamilton RH, Chrysikou EG, Coslett B. Mechanisms of aphasia recovery after stroke and the role of noninvasive brain stimulation. Brain Lang 2011;118:40-50.

8 Reis J, Robertson EM, Krakauer JW, et al. Consensus: can transcranial direct current stimulation and transcranial magnetic stimulation enhance motor learning and memory formation? Brain Stimul 2008;1:363-9.

9 Vallar G, Bolognini N. Behavioural facilitation following brain stimulation: implications for neurorehabilitation. Neuropsychol Rehabil 2011;21:618-49.

10 Webster BR, Celnik PA, Cohen LG. Noninvasive brain stimulation in stroke rehabilitation. NeuroRx 2006;3:474-81.

11 Hallett M. Transcranial magnetic stimulation: a primer. Neuron 2007;55:187-99.

12 Lefaucheur JP. Stroke recovery can be enhanced by using repetitive transcranial magnetic stimulation (rTMS). Neurophysiol Clin 2006;36:105-15.

13 Nitsche MA, Cohen LG, Wassermann EM, et al. Transcranial direct current stimulation: state of the art 2008. Brain Stimul 2008;1:206-23.

14 Schlaug G, Renga V, Nair D. Transcranial direct current stimulation in stroke recovery. Arch Neurol 2008;65:1571-6.

15 Cherney LR. Cortical stimulation and aphasia: the state of the science. Perspect Neurophysiol Neurogenic Speech Lang Disord 2008;18:33-9.

16 Martin PI, Naeser MA, Ho M, et al. Research with transcranial magnetic stimulation in the treatment of aphasia. Curr Neurol Neurosci Rep 2009:9:451-8.

17 Nitsche MA, Liebetanz D, Antal A, et al. Modulation of cortical excitability by weak direct current stimulation-technical, safety and functional aspects. Supp/ Clin Neurophysiol 2003;56:255-76.

18 Poreisz C, Boros K, Antal A, et al. Safety aspects of transcranial direct current stimulation concerning healthy subjects and patients. Brain Res Bull 2007;72:208-14.

19 Brunoni AR, Nitsche MA, Bolognini N, et al. Clinical research with transcranial direct current stimulation (tDCS): challenges and future directions. Brain Stimul 2012;5:175-95

20 Stagg CJ, Nitsche MA. Physiological basis of transcranial direct current stimulation. Neuroscientist 2011:17:37-53.

21 Ardolino G, Bossi B, Barbieri S, et al. Non-synaptic mechanisms underlie the after-effects of cathodal transcutaneous direct current stimulation of the human brain. J Physiol 2005;568:653-63.

22 Bindman LJ, Lippold OC, Redfearn JW. Long-lasting changes in the level of the electrical activity of the cerebral cortex produced bypolarizing currents. Nature 1962;196:584-5.

23 Bindman LJ, Lippold OC, Redfearn JW. The action of brief polarizing currents on the cerebral cortex of the rat (1) during current flow and (2) in the production of long-lasting after-effects. J Physiol 1964;172:369-82.

24 Creutzfeldt OD, Fromm GH, Kapp H. Influence of transcortical d-c currents on cortical neuronal activity. Exp Neurol 1962;5:436-52.

25 Nitsche MA, Paulus W. Excitability changes induced in the human motor cortex by weak transcranial direct current stimulation. J Physiol 2000:527:633-9.

26 Priori A. Brain polarization in humans: a reappraisal of an old tool for prolonged non-invasive modulation of brain excitability. Clin Neurophysiol 2003;114: 589-95.

27 Priori A, Berardelli A, Rona $\mathrm{S}$, et al. Polarization of the human motor cortex through the scalp. Neuroreport 1998;9:2257-60. 
28 Purpura DP, McMurtry JG. Intracellular activities and evoked potential changes during polarization of motor cortex. J Neurophysiol 1965;28:166-85.

29 Liebetanz D, Nitsche MA, Tergau F, et al. Pharmacological approach to the mechanisms of transcranial DC-stimulation-induced after-effects of human motor cortex excitability. Brain 2002;125:2238-47.

30 Nitsche MA, Fricke $K$, Henschke $U$, et al. Pharmacological modulation of cortical excitability shifts induced by transcranial direct current stimulation in humans. J Physiol 2003;553:293-301.

31 Gartside IB. Mechanisms of sustained increases of firing rate of neurons in the rat cerebral cortex after polarization: reverberating circuits or modification of synaptic conductance? Nature 1968;220:382-3.

32 Islam N, Aftabuddin M, Moriwaki A, et al. Increase in the calcium level following anodal polarization in the rat brain. Brain Res 1995;684:206-8.

33 Trollinger DR, Isseroff RR, Nuccitelli R. Calcium channel blockers inhibit galvanotaxis in human keratinocytes. J Cell Physiol 2002;193:1-9.

34 Titushkin I, Cho M. Regulation of cell cytoskeleton and membrane mechanics by electric field: role of linker proteins. Biophys J 2009;96:717-28.

35 Merzagora AC, Foffani G, Panyavin I, et al. Prefrontal hemodynamic changes produced by anodal direct current stimulation. Neuroimage 2010;49: 2304-10.

36 Suzuki K, Fujiwara T, Tanaka N, et al. Comparison of the after-effects of transcranial direct current stimulation over the motor cortex in patients with stroke and healthy volunteers. Int I Neurosci 2012:122:675-81.

37 Ambrus GG, Al-Moyed H, Chaieb L, et al. The fade-in-short stimulation-fade out approach to sham tDCS - reliable at $1 \mathrm{~mA}$ for naive and experienced subjects, but not investigators. Brain Stimul. Published Online First: 23 February 2012. doi:10. 1016/j.brs.2011.12.001

38 Priori A, Hallett M, Rothwell JC. Repetitive transcranial magnetic stimulation or transcranial direct current stimulation? Brain Stimul 2009;2:241-5.

39 Iyer MB, Mattu U, Grafman J, et al. Safety and cognitive effect of frontal DC brain polarization in healthy individuals. Neurology 2005;64:872-5.

40 Bastani A, Jaberzadeh S. Does anodal transcranial direct current stimulation enhance excitability of the motor cortex and motor function in healthy individuals and subjects with stroke: a systematic review and meta-analysis. Clin Neurophysiol 2011;123:644-57

41 Fertonani A, Rosini S, Cotelli $M$, et al. Naming facilitation induced by transcranial direct current stimulation. Behav Brain Res 2010;208:311-18.

42 de Vries $\mathrm{MH}$, Barth AC, Maiworm S, et al. Electrical stimulation of Broca's area enhances implicit learning of an artificial grammar. J Cogn NeurosC 2010;22:2427-36.

43 Liuzzi G, Freundlieb N, Ridder $\mathrm{V}$, et al. The involvement of the left motor cortex in learning of a novel action word lexicon. Curr Biol 2010;20: 1745-51.

44 Cattaneo Z, Pisoni A, Papagno C. Transcranial direct current stimulation over Broca's region improves phonemic and semantic fluency in healthy individuals. Neuroscience 2011;183:64-70.

45 Holland $\mathrm{R}$, Leff $\mathrm{AP}$, Josephs 0 , et al. Speech facilitation by left inferior frontal cortex stimulation. Curr Biol 2011;21:1403-7.

46 Wirth M, Rahman RA, Kuenecke J, et al. Effects of transcranial direct current stimulation (tDCS) on behaviour and electrophysiology of language production. Neuropsychologia 2011;49:3989-98
47 Sparing R, Dafotakis M, Meister IG, et al. Enhancing language performance with non-invasive brain stimulation-a transcranial direct current stimulation study in healthy humans. Neuropsychologia 2008:46:261-8.

48 Floel A, Rosser N, Michka 0, et al. Noninvasive brain stimulation improves language learning. J Cogn Neurosci 2008:20:1415-22.

49 Fiori V, Coccia M, Marinelli CV, et al. Transcranial direct current stimulation improves word retrieval in healthy and nonfluent aphasic subjects. J Cogn Neurosci 2011:23:2309-23.

50 Galdo Alvarez S, Lindin Novo M, Diaz Fernandez F. Naming faces: a multidisciplinary and integrated review. Psicothema 2009:21:521-7.

51 Ross LA, McCoy D, Wolk DA, et al. Improved proper name recall by electrical stimulation of the anterior temporal lobes. Neuropsychologia 2010:48:3671-4.

52 Monti A, Cogiamanian F, Marceglia S, et al. Improved naming after transcrania direct current stimulation in aphasia. J Neurol Neurosurg Psychiatry 2008:79:451-3.

53 Lang N, Nitsche MA, Paulus W, et al. Effects of transcranial direct current stimulation over the human motor cortex on corticospinal and transcallosal excitability. Exp Brain Res 2004;156:439-43.

54 Hesse S, Werner C, Schonhardt EM, et al. Combined transcranial direct current stimulation and robot-assisted arm training in subacute stroke patients: a pilot study. Restor Neurol Neurosci 2007;25:9-15.

55 Baker JM, Rorden C, Fridriksson J. Using transcranial direct-current stimulation to treat stroke patients with aphasia. Stroke 2010;41:1229-36.

56 Marangolo P, Marinelli CV, Bonifazi S, et al. Electrical stimulation over the left inferior frontal gyrus (IFG) determines long-term effects in the recovery of speech apraxia in three chronic aphasics. Behav Brain Res 2011;225:498-504.

57 Kang EK, Kim YK, Sohn HM, et al. Improved picture naming in aphasia patients treated with cathodal tDCS to inhibit the right Broca's homologue area. Restor Neurol Neurosci 2011:29:141-52.

58 Vines BW, Norton AC, Schlaug G. Non-invasive brain stimulation enhances the effects of melodic intonation therapy. Front Psychol 2011:2:230.

59 Jung IY, Lim JY, Kang EK, et al. The factors associated with good responses to speech therapy combined with transcranial direct current stimulation in post-stroke aphasic patients. Ann Rehabil Med 2011;35:460-9.

60 Fridriksson J, Richardson JD, Baker JM, et al. Transcranial direct current stimulation improves naming reaction time in fluent aphasia: a double-blind, sham-controlled study. Stroke 2011:42:819-21.

61 You DS, Kim DY, Chun MH, et al. Cathodal transcranial direct current stimulation of the right Wernicke's area improves comprehension in subacute stroke patients. Brain Lang 2011;119:1-5.

62 Floel $A$, Meinzer M, Kirstein $R$, et al. Short-term anomia training and electrical brain stimulation. Stroke 2011:42:2065-7.

63 Holland R, Crinion J. Can tDCS enhance treatment of aphasia after stroke? Aphasiology 2012:26:1169-91.

64 Coffman BA, Trumbo MC, Flores RA, et al. Impact of tDCS on performance and learning of target detection: interaction with stimulus characteristics and experimental design. Neuropsychologia 2012;50:1594-602.

65 Zaehle T, Sandmann P, Thorne JD, et al. Transcranial direct current stimulation of the prefrontal cortex modulates working memory performance: combined behavioural and electrophysiological evidence. BMC Neurosci 2011;12:2.

66 Loo CK, Alonzo A, Martin D, et al. Transcranial direct current stimulation for depression: 3-week, randomised, sham-controlled trial. Br J Psychiatry 2012;200:52-9. 